Ivana Brdar ${ }^{1}$

Jelena Gajić ${ }^{2}$
JEL:L83, L86, M15, 033, Z31

DOI:10.5937/industrija47-19956

UDC: 005.332.2:005.57

004:007]:338.48(497.11)"2017"

Original Scientific Paper

\title{
IT and Tourism Business - Do Serbian Companies in Tourism Follow Contemporary Trends?
}

\author{
Article history: \\ Received: 19 December 2018 \\ Sent for revision: 21 December 2018 \\ Received in revised form: 25 January 2019 \\ Accepted: 29 January 2019 \\ Available online: 1 April 2019
}

\begin{abstract}
Information technologies are important both for the strategic and operational activities in the tourism and hotel industry. They simultaneously represent opportunities, but also challenges, especially when it comes to the uncertainty of their dynamic development. Since all participants in the tourism and hotel industry compete for an attractive position in the market, IT usage is a must in this process whether it is: internal and external business operations, IT applications for the process of managing business operations and marketing activities or communication with the target groups in a global environment. The aim of the paper is to determine the differences in the degree and method of using IT by the accommodation capacities and tourist agencies (travel agencies and tour operators) in Serbia. In the research conducted in 2017, 209 companies participated, of which 99 were accommodation facilities (hotels, private accommodation, hostels, etc.) and 110 travel agencies and tour operators. Pearson chi square test was used to assess significant differences between groups in terms of nominal data and Mann-Whitney $U$ test for ordinal data. The results showed that Serbian companies use IT in everyday business, but that there are certain differences in the use of different tools and IT capabilities.
\end{abstract}

Keywords: Tourism, Information technology, accommodation facilities, travel agencies, touroperators, Serbia.

\footnotetext{
${ }^{1}$ Singidunum University, Belgrade, Serbia

${ }^{2}$ Singidunum University, Belgrade, Serbia; igajic@singidunum.ac.rs
} 
Brdar I., Gajić J.: IT and Tourism Business - Do Serbian Companies in Tourism...

\section{IT i turističko poslovanje - da li srpska preduzeća u turizmu prate savremene trendove?}

Apstrakt: Informacione tehnologije su značajne kako za strateške, tako i za operativne aktivnosti turističke i hotelijerske industrije. One predstavljaju istovremeno mogućnosti, ali i izazove, posebno kada se ima u vidu neizvesnost njihovog dinamičnog razvoja. $S$ obzirom na to da se svi učesnici u turističkoj i hotelijerskoj industriji takmiče za konkurentnu poziciju na tržištu, IT su neophodnost u ovom procesu bilo da se radi o internim i eksternim poslovnim operacijama, IT aplikacijama za proces upravljanja poslovnim operacijama i marketing aktivnostima ili komunikaciji sa ciljnim grupama $u$ globalnom okruženju. Cilj rada je da se istraži različitost u stepenu i načinu korišćenja IT od strane smeštajnih kapaciteta i turističkih agencija $i$ organizatora putovanja u Srbiji. U istraživanju koje je sprovedeno 2017. godine učestvovalo je 209 preduzeća, od čega 99 smeštajnih kapaciteta (hoteli, privatni smeštaj, hosteli i sl.) i 110 turističkih agencija i organizatora putovanja. Korišćen je Pearson chi square test kako bi se procenile značajne razlike između grupa u smislu nominalnih podataka, a Mann-Whitney U test je korišćen za redne podatke. Rezultati su pokazali da srpska preduzeća koriste IT u svakodnevnom poslovanju, ali da postoje određene razlike u korišćenju različitih alatki i IT mogućnosti.

Ključne reči: turizam, informacione tehnologije, smeštajni kapaciteti, turističke agencije, turoperatori, Srbija.

\section{Introduction}

Information technologies (IT) have greatly influenced the changes in business decision-making of all companies, regardless of the business sector they operate in. Today's market is characterized by the presence of strong competition, which affects the tourism and hotel companies' existence in the market. Some of the opportunities for increasing competitiveness are adapting to changes in the market and improving business, particularly with respect to the application of new information technologies, information systems, and the Internet (Buhalis \& Leung, 2018). Companies that have timely grasped the importance of integrating new technologies into traditional businesses have the opportunity to progress and achieve growth and development as well as a competitive position.

The emergence of information technology in business has caused changes in the hotel and tourism market, which primarily relate to changes in business decision-making and communication with target groups of customers (Drosos et al., 2017). Hotel and tourism companies increasingly focus on e-commerce, 
Brdar I., Gajić J.: IT and Tourism Business - Do Serbian Companies in Tourism...

but also linking in electronic partnerships and creating their own software solutions. The process of globalization inevitably imposes trend monitoring, which affects the redefinition of business decision-making policies in all companies that operate on the side of the tourist offer. Globalization, a process that contributes to changes in society, culture and the world economy, has influenced many changes in modern business - strategic, organizational, communication, and others.

Law and Jogaratnam (2005) believe that the IT application influenced the changing nature of tourism and hotel products, internal processes, business, competitiveness and communication with the environment $(\mathrm{Wu} \&$ Cheng, 2018). In the informational revolution of the tourism and hotel environment, companies that have not integrated IT systems and transformed their business are facing a decline in competitiveness. The business of these companies is accompanied by intensive communication with the internal and external environment, thus, offline communication increasingly replaces online communication with the target groups (Law et al,, 2014).

The special interest of the tourism and hotel industry is the integration of smart technologies in order to create personalized experiences in which competitiveness and high customer expectations drive the need for differentiation (Neuhofer et al., 2015). Travel companies pay special attention to creating better value services. Timely information on tourists and other stakeholders, but also reduction of operating costs, increase of operational efficiency can be achieved using an adequate application of IT in business systems. IT integration in business should provide a better, personalized experience to customers (Neuhofer, 2015), and at the same time increasing the business operations efficiency within the organization (Wu \& Cheng, 2018; Kandampully et al, 2016; Law \& Jogaratnam, 2005).

Bearing in mind the above mentioned, the aim of the paper is to determine the differences in the degree and method of using IT by the accommodation capacities and tourist agencies (travel agencies and tour operators) in Serbia. Accordingly, the hypothesis is that Serbian tourist companies monitor modern trends in the use of IT.

\section{Literature review}

International tourism has been growing faster over the past 5 years than the world goods trade (UNWTO, 2017) and it continues to be one of the main online commercialization sectors. At the beginning of 1980, there was an accelerated growth in the application of information technology (IT) in the tourism industry, and accordingly, this area became the subject of many researchers' interest (Navio-Marco et al., 2018; Neuhofer et al., 2015; Law et 
Brdar I., Gajić J.: IT and Tourism Business - Do Serbian Companies in Tourism...

al., 2014). Today, tourism companies face a number of new challenges arising from changes on the side of tourism demand and in the environment, which have emerged under the influence of new technologies (Li et al., 2017). In order to meet these challenges, companies and participants on the side of the tourist offer must recognize the types of changes that have occurred and then proactively react to them (Soteriades \& Avgeli, 2007; Gretzel, 2011).

New technologies significantly affect the distribution channels in tourism and allow the circumvention of the existing channels and the increasing specialization of tourism enterprises. Buhalis (2008) states that IT can offer a new way of managing for tourism companies, as well as numerous business opportunities that can be applied in order to: gain a competitive advantage, improve productivity and performance, facilitate new management and organizational arrangements, and develop new businesses.

Information technologies can have a wide application in the business of tourism companies. Pender \& Sharpley (2005) state that IT can have strategic and operational functions. From a strategic point, it can contribute to the improvement of existing and development of new tourism products and services, while improving organizational efficiency and effectiveness. IT also allows for easier monitoring of market trends, which makes it easier for the company to differentiate and position itself compared to competition (Pender \& Sharpley, 2005). From the operational point of view, information technology makes it easier to organize front-office and back-office jobs, contributes to faster distribution of information and easier bookkeeping, and improves communication with all stakeholders (Pender \& Sharpley, 2005).

The application of the Internet in tourism business influenced the change in the business decision-making of tourism enterprises (Navio-Marco et al., 2018), especially in terms of collecting, storing, distributing, processing and managing information (Prideaux \& Carson, 2011; Buhalis \& Leung, 2018). There is an increasing number of Internet based tourism services, which in this case constitutes the main communication channel and at the same time ensures lower operating costs. Tourism companies are also involved in Central Reservation Systems (CRS) and Global Distribution Systems (GDS) (Page \& Connell, 2009). By using GDS, different service providers (airline companies, hotels, rent-a-car companies, railways, bus transportation, water transport companies) have the opportunity to offer their services to the entire global market. There are many reasons to use the GDS: in this way companies are present in the global market, have the ability to sell services at points of sale around the world, all information is available to them for twentyfour hours, seven days a week, can reduce operating costs etc. (Pizam, 2005).

The development and application of the Internet in tourism, especially in the mechanisms of business organization, have contributed to great changes in 
Brdar I., Gajić J.: IT and Tourism Business - Do Serbian Companies in Tourism...

this industry (Matias et al., 2009; Buhalis \& Leung, 2018; Navio-Marco et al., 2018). Cooper \& Hall (2008) explains that the Internet also influenced changes in user behaviour patterns in communication, search of information and the purchase of tourism products. A large number of consumers use the Internet to search for other user's tourist experiences, but also to find relevant information on the company whose services they plan to use (Harvey Lemelin et al., 2012).

The Internet also offers a wide range of opportunities for improving the business of tourism business operators, using the advantage of multimedia product presentation, tourist destination, etc. The great significance of the Web in tourism is also a multidimensional presentation of the destination or the very facility that can be visited, making it easier to make choices when shopping (Page \& Connell, 2009). Today tourists, with the help of the Internet and websites, have the possibility to independently book different services. In this way, they find the lowest prices and best packages on the sites that directly belong to the hotels or airlines that they are interested in.

\subsection{Application of information technologies and Internet in hotel industry}

New trends in the hotel industry, created under the influence of globalization, point to the great importance of the application of information technologies in the promotion, especially in the field of daily business operations. Particular emphasis is placed on the use of mobile phones and applications when booking services (Chen et al., 2016), as well as the use of social media (Law et al., 2014.) Furhermore, the tendency of a larger number of domestic but primarily foreign guests, as well as an increase in the quality of services, is emphasized.

It is almost impossible to imagine today's business of hotel companies without the use of information technology in everyday business operations (Kandampully et al., 2016). The rapid development and great accessibility of technology has enabled hotel companies to have their own operating systems, enabling them to conduct business operations (Wu \& Cheng, 2018) such as booking, revenue management, directly communicating with users, and so on (Rutherford \& O'Fallon, 2007).

UNWTO (2001) lists the most important IT tools available to hotel companies: financial management and accounting, and a special role is played by ERP applications; E-Procurement - allows hotel managers to connect with suppliers in a simple way and have full control over costs; linking with tourist portals, which allows for a number of accommodation units to be made 
Brdar I., Gajić J.: IT and Tourism Business - Do Serbian Companies in Tourism...

available through online agencies, which can improve sales; establishing $\mathrm{m}$ shops - creating applications for wireless digital devices and mobile phones, which can significantly improve the sales and process of reservations; Hotel website - presentation of the hotel, with all precise and accurate information, pricelist, and with the possibility of online booking. This reservation system can be linked directly to CRSs, which will greatly facilitate business activities in this area. Also, what is often forgotten is using the website as a promotional element. In order to advance their promotion, hotels can connect with the information systems of other tourist companies. In this way, hotel companies can make available its e-catalogue that will be available to potential clients; Customer Relationship Management (CRM) - By developing an integrated IT infrastructure, CRM can collect large amounts of customer data that can detect patterns of behaviour or create user profiles that will help employees better meet the needs of each client individually. The use of new technologies in hotel furnishing - especially attractive in the last few years, which greatly facilitates the stay of clients in the hotel (smart rooms) (Neuhofer, et al, 2015) and connection with the GDS.

The rapid development of the Internet has significantly affected changes in the promotion and sale of hotel services. As already mentioned, Internet access has provided users with the ability to search for information without limitations, but also reserve and buy tourist services, in this case, hotel services. Similarly, vendors can control their servers remotely in order to provide updated information that is necessary to online users globally. Different sources suggest that the sale of tourist and hotel services online is recording continuous growth (Sutheeshna et al., 2008).

\subsection{Use of information technologies in the business of tour operators and travel agencies}

The main advantage of IT in the business of tour operators and travel agencies is the speed at which their capacities can be managed, increased efficiency in the booking system, and the possibility of any corrections that can be made in a very short time (Law et al., 2004; Lewis et al., 1998). In addition, information technology has made it possible to increase the quality of service delivery, but also to increase the efficiency of front-office (sales of tourism sales) and back-office jobs (marketing, management, administration, etc.) (Lewis et al., 1998; Lewis \& Talalayevsky, 1996). Another positive aspect of computer technology is that hardware and software can also be fully adapted to the needs of small-scale travel agencies, and this can additionally enable them to digitize a large part of their business activities at relatively low cost.

UNWTO (2001) lists the most important IT tools available to travel agencies and tour operators: Website - a presentation of tourist services, with detailed 
Brdar I., Gajić J.: IT and Tourism Business - Do Serbian Companies in Tourism...

information. Some sites offer the possibility of online shopping for travel arrangements, as well as the possibility for online tourists to create their own travel at their own request. Connecting with CSR and GDS systems - allows access to a large number of potential clients, both inside and outside their country of origin. Customer Relationship Management (CRM) - managing customer data, with the aim of retaining them and loyalty rewards. Supply Chain Management - provides connectivity to suppliers. Agency Management Systems - enables computerizing business and accounting and helps in organizing and managing business operations. Integrated product development - provides the ability to design innovative package arrangements, reduce costs and prevent the occurrence of unforeseen losses, and E-marketing.

The use of information systems plays a very important role in carrying out the business of tour operators and travel agencies, and particular changes have been caused by the Internet, especially in the field of distribution and sale of tour packages and other services. The Internet has created numerous challenges for travel agencies (Bédard, 2000). The use of IT has significantly contributed to the improvement of the package arrangement placement. Namely, today all major tour operators have their own CRSs whose application significantly influenced the reduction of costs and accuracy in the reservation process. Furthermore, CRS and GDS have become very important for booking tourist services, but also for gathering all the necessary information about organizing tours and issuing travel documents. According to Smith and Jenner (1994), nearly 30,000 tour operators and travel agencies used at least one GDS. It is important to note that the application of IT can also present a certain type of threat to the previous transaction processing method in organizing travel, especially if it is considered that over time, everything will be replaced by technological solutions, such as electronic ticket sales, electronic transfer of funds, etc. (Pease et al, 2007).

\section{Research on IT application in travel and hotel industry}

\subsection{Statistical methodology}

Bearing in mind the development of the world tourism industry, the main aim of the research is to determine the differences in the degree and method of using IT by the accommodation capacities and tourist agencies (travel agencies and tour operators) in Serbia, in various aspects of business - sales and service bookings, internal business activities, communication with business partners and other stakeholders, as well as promotional activities. In the research conducted in 2017, 209 companies participated, of which 99 
Brdar I., Gajić J.: IT and Tourism Business - Do Serbian Companies in Tourism...

were accommodation facilities (hotels, private accommodation, hostels, etc.) and 110 travel agencies and tour operators (TO\&TA).

Results are presented as count (percent) or median (25-75th percentile), depending on data type. Pearson chi square test was used to assess significant differences between groups regarding nominal data and MannWhitney $U$ test for ordinal data. All $p$ values less than 0.05 were considered significant. All analysis was performed in SPSS 20.0 (IBM corporation) statistical software.

\subsection{Research results}

There is a statistically significant difference between the groups tested by the client and the orientation of the company. While the group that relates to accommodation in a similar relationship is oriented towards domestic, foreign or both, the TO\&TA are predominantly oriented to domestic clients. Both the TO\&TA and the accommodation are predominantly oriented to both individuals and groups, but the difference in percentage is evidently higher when it comes to orientation in relation to groups, in favour of the TO\&TA. The use of IT in business is significantly higher in the group organizer, while the group accommodation has a far greater percentage of IT in the sale of services (Table 1).

Table 1. Information on surveyed companies

\begin{tabular}{|c|c|c|c|}
\hline & \multicolumn{2}{|c|}{ Company } & \multirow[t]{2}{*}{$\mathrm{p}$ value } \\
\hline & Accommodation & TO \& TA & \\
\hline \multicolumn{4}{|l|}{ Clients } \\
\hline Domestic & $27.3 \%$ & $78.2 \%$ & \multirow[t]{3}{*}{$<0.001$} \\
\hline Foreign & $34.3 \%$ & $4.5 \%$ & \\
\hline Both & $38.4 \%$ & $17.3 \%$ & \\
\hline \multicolumn{4}{|l|}{$\begin{array}{l}\text { Company client } \\
\text { orientation }\end{array}$} \\
\hline Individual & $25.3 \%$ & $20.0 \%$ & \multirow[t]{3}{*}{0.032} \\
\hline Groups & $8.1 \%$ & $20.9 \%$ & \\
\hline Both & $66.7 \%$ & $59.1 \%$ & \\
\hline $\begin{array}{l}\text { IT usage in business } \\
\text { activities }\end{array}$ & $88.9 \%$ & $96.4 \%$ & 0.037 \\
\hline IT in service selling & $96.0 \%$ & $68.2 \%$ & $<0.001$ \\
\hline
\end{tabular}

Source: Authors research

The difference between groups is significant in terms of supplier communication. Specifically, there is a significantly higher percentage in the group TO\&TA when it comes to GDS, the supplier's system, while three times 
Brdar I., Gajić J.: IT and Tourism Business - Do Serbian Companies in Tourism...

more responses were in favour of group accommodation when it comes to new electronic intermediators. Regarding the area in which IT is used, the percentage is significantly higher when it comes to the TO\&TA, especially in collecting information, e-mail usage, administration, while the higher percentage is in the group of accommodation when it comes to booking, selling and transferring money. When it comes to IT tools in use, groups differ significantly only in GDS usage and this is for the benefit of the TO\&TA (Table 2).

Table 2. IT usage in companies' business

\begin{tabular}{|c|c|c|c|}
\hline & \multicolumn{2}{|c|}{ Company } & \multirow[t]{2}{*}{$p$ value } \\
\hline & Accommodation & TO\&TA & \\
\hline Business usage of IT & $88.9 \%$ & $96.4 \%$ & 0.037 \\
\hline IT in selling & $96.0 \%$ & $68.2 \%$ & $<0.001$ \\
\hline GDS & $14.1 \%$ & $26.4 \%$ & 0.029 \\
\hline New e-intermediators & $68.7 \%$ & $22.7 \%$ & $<0.001$ \\
\hline Promotion & $77.8 \%$ & $85.5 \%$ & 0.151 \\
\hline Reservation & $80.8 \%$ & $57.3 \%$ & $<0.001$ \\
\hline Selling & $71.7 \%$ & $50.9 \%$ & 0.002 \\
\hline Money transfer & $64.6 \%$ & $50.9 \%$ & 0.045 \\
\hline Other & $0.0 \%$ & $0.9 \%$ & 1 \\
\hline GDS usage & $19.2 \%$ & $23.6 \%$ & 0.435 \\
\hline $\begin{array}{l}\text { Supplier communication } \\
\text { Traditional contracting } \\
\text { Supplier system }\end{array}$ & $\begin{array}{l}78,8 \% \\
28.3 \% \\
\end{array}$ & $\begin{array}{l}83,6 \% \\
44.5 \% \\
\end{array}$ & $\begin{array}{c}0,369 \\
0.015\end{array}$ \\
\hline Other & $3.0 \%$ & $1.8 \%$ & 0.669 \\
\hline \multicolumn{4}{|l|}{ Areas where IT is used } \\
\hline Collecting of information & $69.7 \%$ & $82.7 \%$ & 0.026 \\
\hline Communication with partners & $85.9 \%$ & $88.2 \%$ & 0.617 \\
\hline E-mail & $90.9 \%$ & $98.2 \%$ & 0.019 \\
\hline Administration & $55.6 \%$ & $72.7 \%$ & 0.010 \\
\hline \multicolumn{4}{|l|}{ IT tools in use } \\
\hline Internal system & $60.6 \%$ & $56.4 \%$ & 0.534 \\
\hline Internet & $92.9 \%$ & $96.4 \%$ & 0.267 \\
\hline CRS & $36.4 \%$ & $27.3 \%$ & 0.158 \\
\hline GDS & $13.1 \%$ & $27.3 \%$ & 0.012 \\
\hline Mobile application & $8.1 \%$ & $8.2 \%$ & 0.979 \\
\hline Geographic Information System & $14.1 \%$ & $8.2 \%$ & 0.169 \\
\hline Virtual guide & $8.1 \%$ & $10.9 \%$ & 0.488 \\
\hline Other & $0.0 \%$ & $1.8 \%$ & 0.499 \\
\hline
\end{tabular}

Source: Authors research

There is a far greater percentage in the group of accommodation when it comes to new e-intermediators. Also, it is noted that accommodation group often has multilingual websites. Further, the group accommodation uses more features of the website, especially when it comes to booking a service (Table $3)$. 
Brdar I., Gajić J.: IT and Tourism Business - Do Serbian Companies in Tourism...

Table 3. Internet activities of companies' business

\begin{tabular}{|c|c|c|c|}
\hline & Com & & $p$ value \\
\hline & Accommodation & TO\&TA & \\
\hline Web site & $100 \%$ & $97.3 \%$ & 0.248 \\
\hline Multilingual web site & $82.8 \%$ & $42.0 \%$ & $<0.001$ \\
\hline Updating & & & \\
\hline$>3 \times$ monthly & $18.2 \%$ & $50.0 \%$ & $<0.001$ \\
\hline $2-3 \times$ monthly & $18.2 \%$ & $17.3 \%$ & \\
\hline $1 \times$ monthly & $25.3 \%$ & $15.5 \%$ & \\
\hline $1 \mathrm{x}$ seasonally & $21.2 \%$ & $9.1 \%$ & \\
\hline $1 \mathrm{x}$ in a few months & $17.2 \%$ & $8.2 \%$ & \\
\hline Web site possibilities & & & \\
\hline Presentation & $92.9 \%$ & $96.4 \%$ & 0.267 \\
\hline Reservation & $82.8 \%$ & $40.9 \%$ & $<0.001$ \\
\hline Selling & $20.2 \%$ & $9.1 \%$ & 0.022 \\
\hline Other & $0.0 \%$ & $3.6 \%$ & 0.123 \\
\hline Promotion & & & \\
\hline Catalogues and brochures & $83.8 \%$ & $83.6 \%$ & 0.968 \\
\hline TV and radio ads & $39.4 \%$ & $50.0 \%$ & 0.124 \\
\hline Web presentation & $92.9 \%$ & $87.3 \%$ & 0.174 \\
\hline Social media & $79.8 \%$ & $79.1 \%$ & 0.900 \\
\hline New e-intermediators & $78.8 \%$ & $9.1 \%$ & $<0.001$ \\
\hline Other & $2.0 \%$ & $7.3 \%$ & 0.106 \\
\hline
\end{tabular}

Source: Authors research

Table 4. Companies' attitude on using IT

\begin{tabular}{|l|c|c|c|}
\hline & \multicolumn{2}{|c|}{ Company } & p value \\
\cline { 2 - 3 } & Accommodation & TO\&TA & \\
\hline $\begin{array}{l}\text { IT implementation is expensive so we use traditional } \\
\text { method of business }\end{array}$ & $2(2-2)$ & $2(2-3)$ & 0,729 \\
\hline $\begin{array}{l}\text { IT has improved and facilitated business operations } \\
\text { in the company }\end{array}$ & $4(4-5)$ & $4(4-5)$ & 0,253 \\
\hline $\begin{array}{l}\text { The highest percentage of promotional activities is } \\
\text { done through social media }\end{array}$ & $3(2-4)$ & $4(2-4)$ & 0,149 \\
\hline Face-to-face selling is the best choice & $3(2-4)$ & $4(2-4)$ & 0,001 \\
\hline $\begin{array}{l}\text { Customers rarely buy online products for security } \\
\text { reasons }\end{array}$ & $2(2-2)$ & $3(2-4)$ & $<0,001$ \\
\hline $\begin{array}{l}\text { Comments and reviews on sites are regularly } \\
\text { monitored }\end{array}$ & $4(4-5)$ & $3(2-4)$ & $<0,001$ \\
\hline
\end{tabular}

Source: Authors research 
Brdar I., Gajić J.: IT and Tourism Business - Do Serbian Companies in Tourism...

Comparison of the surveyed groups found that there is a higher score with the TO\&TA group in relation to Face-to-face sales is the best choice, as well as the fact that customers rarely buy online products for security reasons, while the accommodation score is greater when it comes to comments and evaluations they are regularly monitored on the sites (Table 4).

\subsection{Discussion}

The new era of IT enabled the use of a wide range of new tools for the tourism industry, especially in the area of accommodation capacities and business of tour operators and travel agencies. The continuous development of information technologies is reflected in the business of the entities in the tourism market in terms of the constant increase of efficiency in the business of tourist agencies, hotels and other factors of the overall tourism economy. They are applied in all areas of the tourism industry: traffic (airline companies, rental agencies, tourist boats, as well as other transport service providers), in the system of business of travel agencies, hotel companies, business associations, international organizations, etc. (Buonincontri and Micera, 2016; Zorić \& Jorgić, 2017).

Research shows that the most common areas of application of IT are in managing internal business activities (Wei et al., 2001;), in communication with business partners and stakeholders (Sigala, 2018), as well as for the purpose of promotion and sales (Buonincontri \& Micera, 2016; Sigala, 2018), and this research as well confirms that Serbian companies follow world trends.

Various sources suggest that online sale of tourist and hotel services is recording steady growth (Law et al., 2014). This is confirmed by the findings of this research - an increasing number of companies use the services of new e-intermediators, especially in the group of accommodations. The application of the Internet in business has led to the emergence of new electronic agents created by Internet providers, television and journalists, as well as companies from other areas of business. Web sites and portals are an important tool for marketing activities, but they have also greatly influenced the lifestyle changes of service users, since they have enabled them to choose the appropriate tourist services in a simple, easy manner. Competition in online sales over time has become stronger.

With regard to the accommodation sector, Wei et al. (2001) found that in the global hotel industry (a sample of 900 companies around the world) accommodation capacities in Europe and Australia were dealt with in more detail using the Internet and the Web in all business activities, in relation to other continents. A major international hotel company stated that it booked over $50 \%$ of its reservations through its direct central reservation system due to its strong award program (EY, 2015). Having reviewed the obtained results, 
Brdar I., Gajić J.: IT and Tourism Business - Do Serbian Companies in Tourism...

it can be concluded that Serbian companies in tourism are adopting new technologies and using its advantages in their business, but that there are certain differences by groups. Namely, accommodation, unlike TO \& TA, use more the options offered by the website, such as the reservation of services, and multilingual presentation. This can be justified by the orientation of the client's origin. Bearing in mind the growing use of the Internet in the hospitality industry (Buhalis \& Leung, 2018), managers should maximize the use of these technologies and better construct the content of the websites of companies in which they operate.

When it comes to tour operators and travel agencies, the use of information systems has significantly accelerated and improved business operations, especially those related to data entry, calculation and pricing. They also play a major role in managing the internal reservation system, as they maximally facilitate the insight into all available capacities, which prevents the occurrence of overflow, both in accommodation facilities and in means of transport. If the agency deals with e-commerce, the computer system ensures the connection of all branches with a centralized database. The Americas region has dominated the market in online travel space. South America still needs enhanced IT solutions to increase the number of online consumers for travel bookings. The demand for IT services from this region is expected to drive growth in the service segment in the Americas during the forecast period (Global report, 2018). The marketing methods of travel agencies in the U.S. have changed over the last few years, with many more travel agents using social media as a marketing tool. Travel management, like many things, is becoming more and more web-based. In 2016, digital travel sales in the United States amounted to 180.6 billion US dollars. This figure was forecasted to exceed 213 billion U.S. dollars by 2020 (Statista, 2018). The examined TO \& TA use IT in the internal business and in the promotion, but the online booking and sales option is not sufficiently developed, as opposed to accommodation group.

Considering the above mentioned, we can say that the hypothesis reading that Serbian tourist companies monitor modern trends in the use of IT is confirmed, but the limitations in the research lies in the fact that Serbian companies do not use all the opportunities offered by new IT, which certainly leaves room for future research, in order to determine changes in the use of new tools and technologies that are current in the world, especially when it comes to smart technologies like Big data, Internet of things, mobile technologies (Chen et al., 2016; Neuhofer et al., 2015; Brdar et al., 2018), etc. 
Brdar I., Gajić J.: IT and Tourism Business - Do Serbian Companies in Tourism...

\section{Conclusion}

Bearing in mind the dynamics of changes in the global market, accommodation capacities and tour operators and travel agencies will continue to adapt to new rules and will continue to monitor current trends both in terms of linking and internationalizing business, as well as from the aspect of the product range expansion, improvement of service quality, application of innovations and the permanent use of new information technologies.

The results of the survey indicate that most organizations have recognized multiple benefits in the business after applying IT in their day-to-day operations and that traditional ways of doing business are no longer viable. Also, it can be concluded that Serbian companies use IT in everyday business, but that there are certain differences in the use of different tools and IT capabilities.

The main findings show that the difference between groups is significant in terms of supplier communication. Regarding the area in which IT is used, the percentage is significantly higher when it comes to the TO\&TA, especially in collecting information, e-mail usage, administration, while the higher percentage is in the group of accommodation when it comes to booking, selling and transferring money. There is a far greater percentage in the group of accommodation in terms of new e-intermediators than the TO\&TA. Also, findings show that there is a higher score with the TO\&TA group in relation to face-to-face sales that is the best choice in dealing with customers, as well as the fact that customers rarely buy online products for security reasons, while the accommodation score is greater when it comes to comments and evaluations that are regularly monitored on the sites.

The Serbian tourism companies follow contemporary trends in the field of IT, but do not fully use their possibilities and advantages. Therefore, there is a need for more intensive cooperation between educational institutions and government institutions. This cooperation should help continuing educational programs which would help tourism industry personnel to adopt and accept contemporary IT trends.

Although IT contributes to improving the business of hotel and tourism companies (updating information, quickly and easily creating arrangements, prices, etc.), especially when it comes to simplifying business operations, it is important to note that a significant number of them failed to fully utilize its advantages and opportunities, which can be attributed to the lack of a strategic vision in the application of new communication technologies, as well as management's unwillingness to invest in them. It is anticipated that the sale of travel products will continue to develop over the Internet, which will greatly contribute to endangering the role of traditional intermediaries. More 
Brdar I., Gajić J.: IT and Tourism Business - Do Serbian Companies in Tourism...

precisely, it is anticipated that intensive e-commerce will lead to the disappearance of intermediaries in sales, especially those who did not provide added value to users of travel services. Otherwise, tourism companies that adapt to changing business conditions in the tourist market will have good prospects for their growth and development.

\section{References}

Bédard, F. (2000). Tomorrow's Travel Agency: A Survey of Adaptation And Positioning Strategics to New Technologies in Services. In D.R. Fesenmaier, S. Klein, \& D. Buhalis (Eds.), Information and Communication Technologies in Tourism 2000. (pp. 336-342). Vienna: Springer Nature. doi:10.1007/978-3-7091-6291-0_30

Brdar, I., Živković, R., Gajić, J., Stanković, J., \& Kilibarda, N. (2018). Smart turizam mogućnost primene interneta stvari u savremenom turističkom poslovanju. In Proceedings of the International Scientific Conference - Sinteza 2018. (pp. 116-122). Belgrade, Serbia: Singidunum University. doi:10.15308/sinteza-2018$116-122$

Buhalis, D. (2008). eTourism Case Studies Management and Marketing Issues. Oxford: Elsevier.

Buhalis, D., \& Leung, R. (2018). Smart hospitality-Interconnectivity and interoperability towards an ecosystem. International Journal of Hospitality Management, 71, 41-50. doi:10.1016/j.ijhm.2017.11.011

Buonincontri, P., \& Micera, R. (2016). The experience co-creation in smart tourism destinations: a multiple case analysis of European destinations. Information Technology and Tourism, 16(3), 285-315. doi:10.1007/s40558-016-0060-5

Chen, M., Murphy, H.C., \& Knecht, S. (2016). An Importance Performance Analysis of smartphone applications for hotel chains. Journal of Hospitality and Tourism Management, 29, 69-79. doi:10.1016/j.jhtm.2016.05.001

Cooper, C., \& Hall, C.M. (2008). Contemporary Tourism: An International Approach. Oxford: Elsevier BV.

Drosos, D., Chalikias, M., Skordoulis, M., Kalantonis, P., \& Papagrigoriou, A. (2017). The Strategic Role of Information Technology in Tourism: The Case of Global Distribution Systems. (pp. 207-219). Cham: Springer Nature. doi:10.1007/978-3-319-47732-9_15

-EY. (2015). Global hospitality insights Top thoughts for 2015. https: //www. ey. com/Publication/vwLUAssets/ey-global-hospitality-insights-2015/\$File/ey-globalhospitality-insights-2015.pdf.

Gretzel, U. (2011). Intelligent systems in tourism: A social science perspective. Annals of Tourism Research, 38(3), 757-779. doi:10.1016/j.annals.2011.04.014

Lemelin, H.R., Dawson, J., \& Stewart, E. (2012). Last Chance Tourism Adapting tourism opportunities in a changing world. New York: Routledge.

https://www.statista.com/topics/1859/travel-agencies/.

Kandampully, J., Bilgihan, A., \& Zhang, T.(. (2016). Developing a people-technology hybrids model to unleash innovation and creativity: The new hospitality frontier. Journal of Hospitality and Tourism Management, 29, 154-164. doi:10.1016/j.jhtm.2016.07.003 
Brdar I., Gajić J.: IT and Tourism Business - Do Serbian Companies in Tourism...

Law, R., \& Jogaratnam, G. (2005). A study of hotel information technology applications. International Journal of Contemporary Hospitality Management, 17(2), 170-180. doi:10.1108/09596110510582369

Law, R., Buhalis, D., \& Cobanoglu, C. (2014). Progress on information and communication technologies in hospitality and tourism. International Journal of Contemporary Hospitality Management, 26(5), 727-750. doi:10.1108/ijchm-082013-0367

Law, R., Leung, K., \& Wong, R. (2004). The impact of the Internet on travel agencies. International Journal of Contemporary Hospitality Management, 16(2), 100-107. doi:10.1108/09596110410519982

Lewis, I., \& Talalayevsky, A. (1996). Travel agents: Threatened intermediaries. Transportation Journal, 36(3), 26-30.

Lewis, I., Semeijn, J., \& Talalayevsky, (1998). The Impact of Information Technology on Travel Agents. Transportation Journal, 37(4); 20-25.

Li, Y., Hu, C., Huang, C., \& Duan, L. (2017). The concept of smart tourism in the context of tourism information services. Tourism Management, 58, 293-300. doi:10.1016/j.tourman.2016.03.014

Matias, Á., Nijkamp, P., \& Sarmento, M. (2009). Advances in Tourism Economics. Heidelberg: Springer Nature. doi:10.1007/978-3-7908-2124-6

Navío-Marco, J., Ruiz-Gómez, L.M., \& Sevilla-Sevilla, C. (2018). Progress in information technology and tourism management: 30 years on and 20 years after the internet - Revisiting Buhalis \& Law's landmark study about eTourism. Tourism Management, 69, 460-470. doi:10.1016/j.tourman.2018.06.002

Neuhofer, B., Buhalis, D., \& Ladkin, A. (2015). Smart technologies for personalized experiences: a case study in the hospitality domain. Electronic Markets, 25(3), 243-254. doi:10.1007/s12525-015-0182-1

Page, S.J., \& Connell, J. (2009). Tourism a modern synthesis. Hampshire: Cengage Learning. third edition.

Pease, W., Rowe, M., \& Cooper, M. (2007). Information and Communication Technologies in Support of the Tourism Industry. London: Idea Group Publishing.

Pender, L., \& Sharpley, R. (2005). The Management of Tourism. London: Sage Publication. str. 234.

Pizam, A. (2005). International Encyclopedia of Hospitality Management. Informa UK Limited. doi:10.4324/9780080454849

Prideaux, B., \& Carson, D. (2011). Drive Tourism Trends and emerging markets. New York: Routledge.

Sigala, M. (2017). Market Formation in the Sharing Economy: Findings and Implications from the Sub-economies of Airbnb. In: S. Barile, M. Pellicano, \& F. Polese (Eds.), Social dynamics in a systems perspective. Verlag: Springer Nature.159-174. ISSN 2039-411X.

Smith, C., \& Jenner, P. (1994). Travel agents in Europe. Travel and Tourism Analyst, No. 4, 5-15.

Soteriades, M., \& Avgeli, V. (2007). Promoting tourism destinations: A strategic marketing approach. Tourism Review,55(3), pp. 335-345. UDC: 338.487:659.1.

Sutheeshna, S.(., Mishra, S., \& Bhusan, P.B. (2008). Tourism Development Revisited: Concepts, Issues and Paradigms. London: SAGE Publications. doi:10.4135/9788132100058 
Brdar I., Gajić J.: IT and Tourism Business - Do Serbian Companies in Tourism...

-UNWTO. (2017). Panorama OMT del turismo internacional. www.eunwto.org/doi/book/10.18111/9789284419043.

-UNWTO. (2001). E-business for tourism: Practical guidelines for tourism destinations and business. Madrid.

Wei, S., Ruys, H.F., van Hoof, H.B., \& Combrink, T.E. (2001). Uses of the Internet in the global hotel industry. Journal of Business Research, 54(3), 235-241. doi:10.1016/s0148-2963(00)00117-x

$\mathrm{Wu}, \mathrm{H}_{\text {., }}$ \& Cheng, C. (2018). Relationships between technology attachment, experiential relationship quality, experiential risk and experiential sharing intentions in a smart hotel. Journal of Hospitality and Tourism Management, 37, 42-58. doi:10.1016/j.jhtm.2018.09.003

Zorić, O., \& Jorgić, (. (2017). Uticaj primene informaciono-komunikacione tehnologije na povećanje efikasnosti menadžmenta u turizmu. In UDEKOM Balkan, Second International Thematic Monograph - Thematic Proceedings Modern Management Tools and Economy of Tourism Sector in Present Era. Belgrade. pp. 444-460. 